\title{
Biomedical Engineering and Prehospital Emergencies: Binomial of the Future
}

\author{
Castejón-de la Encina $\mathrm{ME}^{1}$ and Castejón-Lope $\mathrm{G}^{2 *}$ \\ ${ }^{1}$ Prehospital Emergency Nurse, Spain \\ ${ }^{2}$ Biotechnology Engineering Degree student, Spain
}

*Corresponding author: Castejón-Lope G, Biotechnology Engineering Degree student, Spain

\begin{tabular}{|c|c|}
\hline ARTICLE INFO & ABSTRACT \\
\hline Received: 慧 May 21, 2019 & Citation: Castejón-de la Encina ME, Castejón-Lope G. Biomedical Engineering and Pre- \\
\hline Published: 㓞 May 28, 2019 & $\begin{array}{l}\text { hospital Emergencies: Binomial of the Future. Biomed J Sci \& Tech Res 18(2)-2019. } \\
\text { BJSTR. MS.ID.003139. }\end{array}$ \\
\hline
\end{tabular}

\section{Opinion}

Biomedical engineering is a relatively new science in the academic field. Its development has allowed to introduce cuttingedge technology in medical applications with different purposes and unsuspected results. In this opinion article, we will focus on its application, present and future, in the field of prehospital created for it, in order to assess, diagnose and treat the patient clinically during their transfer to the useful hospital center [1]. In Medicine and Nursing Degrees [2,3] biotechnology was introduced, especially through clinical simulation. The high-fidelity mannequins with physiological response are a clear exponent. They are used both for the acquisition of students of both basic and advanced skills, as well as training when working in multidisciplinary teams. In a second phase [4] these same mannequins are used for a first evaluation of the students before their clinical practices thanks to the approach of clinical cases. Currently, holograms [5] and other technological means are used to study in depth the physiology and physiopathology, as well as the anatomy, of the human body.

The postgraduate training of health personnel working in emergency medical services has the following objectives: first, to provide individual, specialized training in the field of emergency; Another aim is the continuous training of health teams, and a third objective would be to form high-performance teams [6]. For this, not only do we have the clinical simulation, we also have augmented virtual reality, immersive virtual reality, CAVE's, [7] etc. That they give us a great methodological variety for the learning of the emergency team students in different situations or in different cases of seriousness, the student can repeat as many times as he wishes until he has acquired skills, non-technical skills or simply having the immersive experience in the emergency field. For this, it is necessary to and medical emergency situations teams with engineers and health specialists about teaching and medical emergency situations. Teams that complement each other and mark the difference, in a transdisciplinary way, between current and future training. At the moment we live a very productive moment in this sense. It innovates in products present in ambulances, such as the "Smart Bench ${ }^{\mathrm{TM}}$ ", [8] platform that allows to know the real weight of any patient, facilitating the calculation of pharmaceutical doses, fluids, etc. reducing human error or devices traditionally anchored to the hospital environment, such as the CT scanner housed inside an ambulance to detect stroke immediately and effectively, thanks to the technical advances of biomedical engineering [9]. Many other examples could be cited. The most important one is to provide the mobile units with technical means to be able to obtain the traceability of the decisions made during the emergency to increase the safety of our patients and thus their survival. In conclusion, to affirm that health professionals and engineers of different specialties enrich health care when we join in $\mathrm{R}+\mathrm{D}+\mathrm{i}$ projects in transdisciplinary teams.

\section{References}

1. Jiménez Fábrega X, Espila JL, Gallardo Mena J (2011) Activation codes: past, present and future in Spain. Emergencies 23: 311-318.

2. Coyer C, Gascoin G, Sentilhes L, Savagner C, Berton J, et al. (2014) Evaluation of the impact and efficiency of high-fidelity simulation for neonatal resuscitation in midwifery education. Arch Pediatr 21(9): 968975.

3. Sherwood RJ, Francis G (2018) The effect of mannequin fidelity on the 
achievement of learning outcomes for nursing, midwifery and allied healthcare practitioners: Systematic review and meta-analysis. Nurse Educ Today 69: 81-94.

4. Gockel I, Hakman P, Beardi J, Schütz M, Heinrichs W, et al. (2008) New perspectives in laparoscopic simulation: from students' skills lab to stress evaluation. T Zentralbl Chir 2133(3): 244-249.

5. Gorman PJ, Meier AH, Rawn C, Krummel TM (2000) The future of medical education is no longer blood and guts, it is bits and bytes. Am J Surg 180(5): 353-356

6. Salas E, Castejón de la Encina ME, del Moral Vicente Mazariegos I (2018) Training of high performance teams in prehospital medical emergency services and clinical safety. In: Castejón-de la Encina ME, Clinical Safety

\section{ISSN: 2574-1241}

DOI: 10.26717/BJSTR.2019.18.003139

Castejón-Lope G. Biomed J Sci \& Tech Res

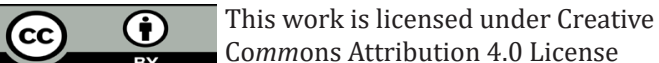

Submission Link: https://biomedres.us/submit-manuscript.php in prehospital emergency services. Elsevier.

7. Rockstraw R, Castejón de la Encina ME, Rubio-Martinez R (2018) Simulation in preschool settings as a tool for clinical safety work. In: Castejón-de la Encina ME, Clinical Safety in prehospital emergency services. Elsevier

8. Castejón de la Encina ME, García-Aracil N, Metcalff II D (2018) Welfare compartment of land vehicles: safety and maintenance elements. In: Castejón-de la Encina ME, Clinical Safety in prehospital emergency services. Elsevier.

9. John S, Stock S, Cerejo R, Uchino K, Winners S, et al. (2016) Brain Imaging Using Mobile CT: Current Status and Future Prospects. J Neuroimaging 26(1): 5-15.

$\begin{array}{ll}\text { BIOMEDICAL } & \text { Assets of Publishing with us } \\ \text { RESEARCHES } & \text { - Global archiving of articles } \\ & \text { - Immediate, unrestricted online access } \\ & \text { - Rigorous Peer Review Process } \\ \end{array}$

